Few, A. V. (1954). J. gen. Microbiol. 10, 304-308

\title{
Electron Microscopy of Disrupted Bacteria treated with Polymyxin E
}

\author{
BY A. V. FEW \\ Department of Colloid Science, University of Cambridge
}

\begin{abstract}
SUMMARY: Mechanically disrupted cells of polymyxin E sensitive strains of Pseudomonas denitrificans and Escherichia coli and a resistant strain of Staphylococcus aureus were studied in the electron microscope. The occurrence of a secondary layer or membrane was observed within the outer cell walls derived from Ps. denitrificans and $E$. coli; a similar structure was not observed in cell walls prepared from Staph. aureus. Treatment of the disrupted cells of Ps. denitrificans and $\boldsymbol{E}$. coli with polymyxin $\mathrm{E}$ resulted in marked morphological changes, whilst similar exposure of Staph. aureus cell walls to the antibiotic produced no significant changes in their morphology.
\end{abstract}

From studies on the absorption of polymyxin $\mathrm{E}$ by intact bacteria and by bacterial cell-wall preparations, it has been shown that polymyxin-sensitive bacteria and cell walls are capable of rapidly absorbing much greater quantities of the antibiotic than similar preparations of resistant bacteria (Few \& Schulman, $1953 a, b)$. The differences in absorption behaviour were especially marked at low concentrations of polymyxin in the supernatant. As a result of the absorption of polymyxin by sensitive bacteria cell solutes were released by the organisms into the supernatant fluids, and it was suggested that polymyxin caused a disorganization of the structure responsible for osmotic regulation in sensitive bacteria.

It was considered that a study, by means of the electron microscope, of the action of the polymyxin $\mathrm{E}$ upon bacterial cell-wall preparations might yield direct evidence of cellular damage. The electron microscope studies of Mitchell \& Crowe (1947) first demonstrated cytolytic damage caused by a bactericidal agent. Further investigations by Dyar (1947), by Meisel \& Umanskaya (1949) and by Salton, Horne \& Cosslett (1951) on the action of detergents of the quarternary ammonium type upon bacterial and yeast cells, demonstrated that in detergent-treated cells the cytoplasm contracted away from the cell envelope. Using intact Pseudomonas aeruginosa, Newton (1953) demonstrated that treatment of the organisms with polymyxin caused a leakage of cell solutes and was accompanied by changes in the morphology of the cells. The above authors observed changes in the morphology of intact cells when exposed to the bactericidal agents. The presence of electron-dense cytoplasmic material can cause difficulty in the observation of possible cellwall changes brought about by the bactericidal agents; only a thin layer of the cell wall at the periphery of the cells can be seen clearly. With the exception of the work of Salton (1952) on the action of lysozyme upon cell walls derived from Micrococcus lysodeikticus, there appears to be little published data on electron microscope observations of the action of bactericidal agents upon isolated bacterial cell walls. The present paper is concerned with the morpho- 
logical changes brought about by the absorption of polymyxin $\mathbf{E}$ by preparations of disrupted bacteria derived from sensitive strains of $\boldsymbol{P} \boldsymbol{s}$. denitrificans and Escherichia coli, and those obtained from a resistant strain of Staphylococcus aureus.

\section{METHODS}

\section{Preparation of disrupted bacteria}

The three organisms investigated, Ps. denitrificans, E. coli and Staph. aureus, were of the same strains as those used previously (Few \& Schulman, 1953 $a, b$ ). Bacterial cells, obtained from $16 \mathrm{hr}$. cultures grown on a beef tryptic digest agar medium, were thrice washed with $0.01 \mathrm{~m}$-phosphate buffer $(\mathrm{pH} 6 \cdot 3)$. The cells were resuspended to $c .10 \mathrm{mg}$. dry wt./ml. in the buffer solution. Nine $\mathrm{ml}$. of the bacterial suspensions were shaken in a Mickle disintegrator with an equal volume of no. 12 glass ballotini beads (English Glass Co., Ltd., Empire Road, Leicester). The shaking process was allowed to continue until most of the cells had been disrupted; a 5 min. shaking period was generally sufficient to cause the rupture of $c .95 \%$ of the cells. The preparations were subjected to differential centrifugation to remove intact bacteria and debris.

\section{Preparation of specimens for the electron microscope}

Suspensions of the disintegrated bacteria at $c .0 \cdot 15 \mathrm{mg}$. dry wt./ml. in 0.01 M-phosphate buffer ( $\mathrm{pH} \mathrm{6.3)}$ were treated with a range of polymyxin $\mathrm{E}$ concentrations so chosen as to give both complete and incomplete saturation of the absorbing sites with the antibiotic. Samples of untreated and polymyxin E-treated suspensions were incubated at $25^{\circ}$ for $20 \mathrm{~min}$. The disintegrated bacteria were then centrifuged and resuspended in distilled water after the supernatant solutions had been removed. Drops of these distilled-water suspensions were placed on copper electron microscope specimen grids which had been covered with a thin nitro-cellulose film. Samples of the intact bacteria were also mounted in the same fashion. The specimens were dried in a desiccator over phosphorus pentoxide under reduced pressure. They were then shadowed with gold + palladium alloy $(60 \%+40 \%)$ at an angle of $30^{\circ}$ to the plane of the specimen grid. A large number of mounted specimens were examined in a Siemens electron microscope, generally at direct magnifications of $\times 12,000-15,000$.

\section{RESULTS}

Plate 1, fig. 1, Pl. 2, fig. 5, and Pl. 3, fig. 9, show the appearance of intact cells of Ps. denitrificans, E. coli and Staph. aureus. In all cases the cytoplasm has contracted away from the cell wall, which can be seen as a layer of uniform thickness. With the exception of Staph. aureus the intact bacteria cast very little shadow and seemed to lie flat on the supporting nitrocellulose film.

Plate 1, fig. 2, shows a typical preparation of disintegrated cells of Ps. denitrificans; the electron-dense cytoplasm has been removed, leaving the deflated cell walls. This preparation shows evidence of a duplex structure, consisting of an outer envelope or cell wall, together with a secondary inner layer which has contracted away from the outer cell wall. The uniform thickness of the 
inner layer suggests that it is not residual cell cytoplasm which, if present, generally occurs as irregular patches of electron-dense material. This inner layer is not complete in all the disrupted cells of Ps. denitrificans, and it appears that the layer can be readily detached from the outer cell wall.

The treatment of these disrupted bacteria with polymyxin $\mathbf{E}$ produced marked morphological changes. PI. 1, figs. 3 and 4, show preparations which were exposed to 20 and $500 \mu \mathrm{g}$. polymyxin $\mathrm{E} / \mathrm{ml}$., respectively. The lower concentration gave rise to an absorption by the disrupted bacteria, which corresponded to the amount absorbed by these structures in the intact organisms when the cells were treated with just sufficient polymyxin $\mathrm{E}$ to give $c .99 \%$ mortality in $20 \mathrm{~min}$. at $25^{\circ}$. The higher concentration used gave rise to complete saturation of the disrupted bacteria with the antibiotic, and corresponded to complete killing of the intact bacteria. The exposure of these preparations to polymyxin $\mathbf{E}$ resulted in a swelling of the bacterial structures. This swelling did not take place in a uniform manner, but resulted in the production of a mosaic pattern which is most clearly seen in Pl. 1, fig. 4 .

The appearance of disrupted cells of $E$. coli (Pl. 2, fig. 6) is similar to that of $P$ s. denitrificans. The treatment of the disrupted cells of $\boldsymbol{E}$. coli with polymyxin $\mathbf{E}$ also caused a disorganization of the cellular material. Pl. 2, figs. 7 and 8 , show the appearance of these disrupted bacteria after exposure to 10 and $200 \mu \mathrm{g}$. polymyxin E/ml., respectively. Pl. 3, fig. 10, shows cell walls derived from polymyxin E-resistant cells of Staph. aureus. Pl. 3, figs. 11 and 12, show the appearance of these cell walls after they were treated with 20 and $200 \mu \mathrm{g}$. polymyxin $\mathrm{E} / \mathrm{ml}$. respectively. The examination of large numbers of disrupted Staph. aureus gave no indication of a duplex structure for these disrupted bacteria. Moreover, treatment of these preparations with polymyxin $\mathbf{E}$ did not result in any significant changes in appearance similar to those obtained with disrupted cells of $\boldsymbol{P}$ s. denitrificans or $\boldsymbol{E}$. coli.

\section{DISCUSSION}

By careful rupture of cells of $\boldsymbol{P}$ s. denitrificans and $\boldsymbol{E}$. coli it has been shown that the resulting disrupted cells possess a duplex structure, consisting of an outer cell wall and an inner secondary layer. It is evident that, whilst this inner layer possesses a certain structural rigidity, it is not so robust as the outer cell wall. Indeed prolonged shaking of the bacterial suspensions in the Mickle disintegrator produces from these organisms cell walls which are devoid of the secondary inner layer. The electron micrographs of partially autolysed cells of Proteus vulgaris and $E$. coli, obtained by Houwink \& van Iterson (1950), clearly show the presence of a secondary layer or membrane within the cell wall of the organisms. Evidence of a similar layer can be seen at the periphery of the intact cell of Ps. denitrificans at the base of Pl. 1, fig. 1, of the present investigation.

Indirect evidence for the existence of this layer was also given by Salton $\&$ Horne (1951), who studied methods for the preparation of bacterial cell walls by the injection of bacterial suspensions into hot water. These authors noted 
that the cell cytoplasm, which had been removed from the cell walls of rodshaped organisms, retained the original shape of the organisms. They suggested that this effect might either be due to the presence of another 'membrane' enclosing the cytoplasm or was caused by the heat coagulation of the cytoplasm, or by a combination of both. The results obtained in the present investigation provide strong support for the existence of an inner membrane within the cell walls of $\boldsymbol{P}$ s. denitrificans and $\boldsymbol{E}$. coli. From the work of Few $\&$ Schulman $(1953 a, b)$ and from the present investigations, it is evident that the permeability alterations brought about by the exposure of sensitive intact bacteria to polymyxin $\mathrm{E}$, and which result in the leakage of cell solutes, can be correlated with morphological changes observed with polymyxin $\mathrm{E}$-treated disrupted bacteria. It is tempting to suggest that the primary site of attack of this antibiotic is at the inner layer of these duplex structures, and that this inner layer or membrane is closely associated with osmotic-pressure regulation in the intact cell. The apparent absence of this membrane from cell-wall preparations of the polymyxin-resistant Staph. aureus, and the lack of any pronounced morphological changes when these preparations are exposed to the antibiotic, would perhaps support this view.

The author wishes to thank the Medical Research Council for a personal grant, Dr J. H. Schulman, O.B.E., and Dr V. E. Cosslett for helpful discussions, and Mr H. Pearson and Miss E. Green for taking the electron micrographs.

\section{REFERENCES}

Dyar, M. T. (1947). A cell wall stain employing a cationic surface-active agent as a mordant. J. Bact. 53, 498.

Few, A. V. \& Schulman, J. H. (1953a). Absorption of polymyxin by bacteria. Nature, Lond. 171, 644.

Few, A. V. \& Schulman, J. H. (1953b). The absorption of polymyxin $E$ by bacteria and bacterial cell walls and its bactericidal action. J. gen. Microbiol. 9, 454.

Houwink, A. L. \& Iterson, W. van (1950). Electron microscopical observations on bacterial cytology. II. A study on flagellation. Biochim. biophys. Acta, 5, 10.

Meisel, M. N. \& Umanskaya, V. P. (1949). On the action of quaternary ammonium compounds on the bacterial cell. Mikrobiologya, Moscow, 18, 11.

Mitchell, P .D. \& Crowe, G. R. (1947). A note on electron micrographs of normal and tyrocidin-lysed streptococci. J. gen. Microbiol. $1,85$.

Newton, B. A. (1953). The release of soluble constituents from washed cells of Pseudomonas aeruginosa by the action of polymyxin. J. gen. Microbiol. 9, 54 .

Salton, M. R. J. (1952). Cell wall of Micrococcus lysodeikticus as the substrate of lysozyme. Nature, Lond. 170, 746.

Salton, M. R. J. \& Horne, R. W. (1951). Studies of the bacterial cell wall. I. Electron microscopical observations on heated bacteria. Biochim. biophys. Acta, 7, 19.

Salton, M. R. J., Horne, R. W. \& Cosslett, V. E. (1951). Electron microscopy of bacteria treated with cetyltrimethyl-ammonium bromide. J. gen. Microbiol. 5, 405. 


\section{EXPLANATION OF PLATES}

\section{Plate 1}

Fig. 1. Intact cells of Pseudomonas denitrificans. $\times 20,000$.

Fig. 2. Disrupted cells of Ps. denitrificans. Note the presence of an inner uniform layer within the cell wall. $\times 20,000$.

Fig. 3. Disrupted cells of Ps. denitrificans after treatment with $20 \mu \mathrm{g}$. polymyxin E/ml. for $20 \mathrm{~min}$. at $25^{\circ} . \quad \times 20,000$.

Fig. 4. Disrupted cells of Ps. denitrificans after treatment with $500 \mu \mathrm{g}$. polymyxin $\mathrm{E} / \mathrm{ml}$. for $20 \mathrm{~min}$. at $25^{\circ} . \times 20,000$.

\section{Plate 2}

Fig. 5. Intact cells of Escherichia coli. 20,000.

Fig. 6. Disrupted cells of $\boldsymbol{E}$. coli. Note the presence of an inner layer within the cell wall. $\times 20,000$.

Fig. 7. Disrupted cells of $E$. coli after treatment with $10 \mu \mathrm{g}$. polymyxin $\mathrm{E} / \mathrm{ml}$. for $20 \mathrm{~min}$. at $25^{\circ} . \times 20,000$.

Fig. 8. Disrupted cells of $E$. coli after treatment with $200 \mu$ g. polymyxin $E / m l$. for $20 \mathrm{~min}$. at $25^{\circ} . \times 20,000$.

\section{Plate 3}

Fig. 9. Intact cells of Staphylococcus aureus. $\times 20,000$.

Fig. 10. Cell walls of Staph. aureus. $\times 20,000$.

Fig. 11. Cell walls of Staph. aureus after treatment with $20 \mu \mathrm{g}$. polymyxin $\mathrm{E} / \mathrm{ml}$. for $20 \mathrm{~min}$. at $25^{\circ} . \times 20,000$.

Fig. 12. Cell walls of Staph. aureus after treatment with $200 \mu \mathrm{g}$. polymyxin $\mathrm{E} / \mathrm{ml}$. for $20 \mathrm{~min}$. at $25^{\circ} . \times 20,000$.

(Received 25 September 1953) 
Journal of General Microbiology, Vol. 10, No. 2
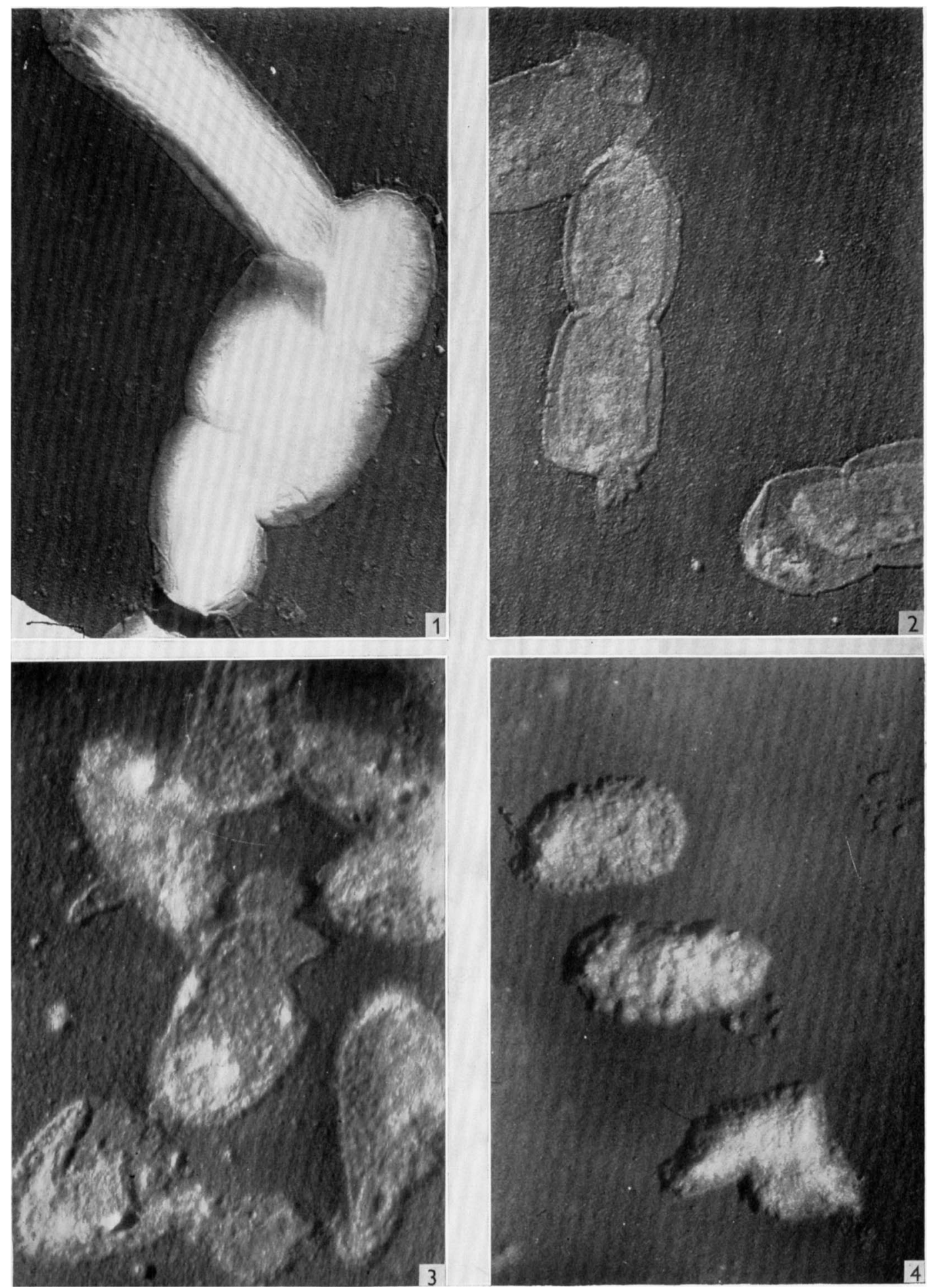

A. V. Few-Polymyxin-treated diskupted bacteria. Plate 1 
Journal of General Microbiology, Vol. 10, No. 2
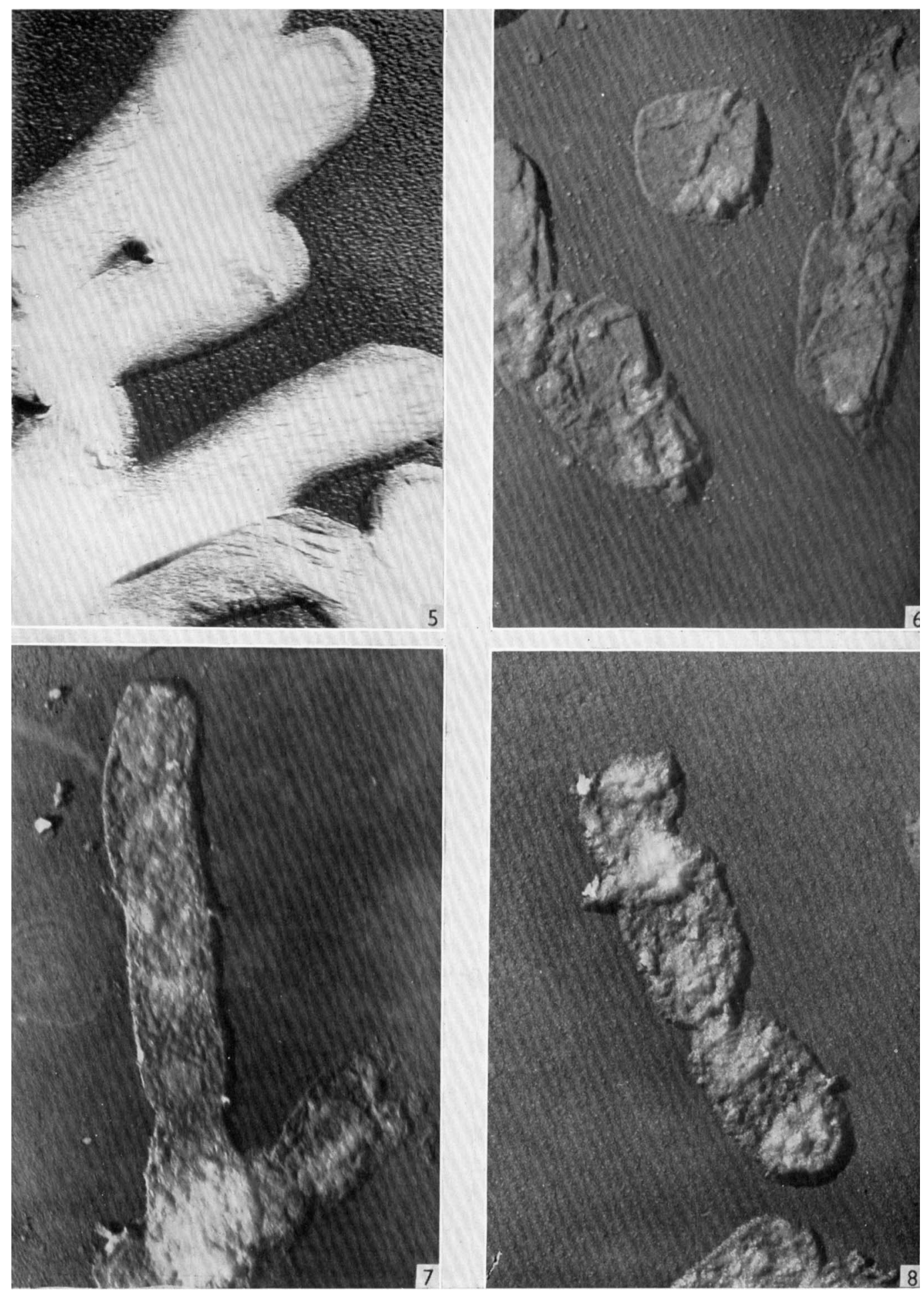

A. V. Few-Polymyxin-treated diskupted bacteria. Piate 2 
Journal of General Microbiology, Vol. 10, No. 2
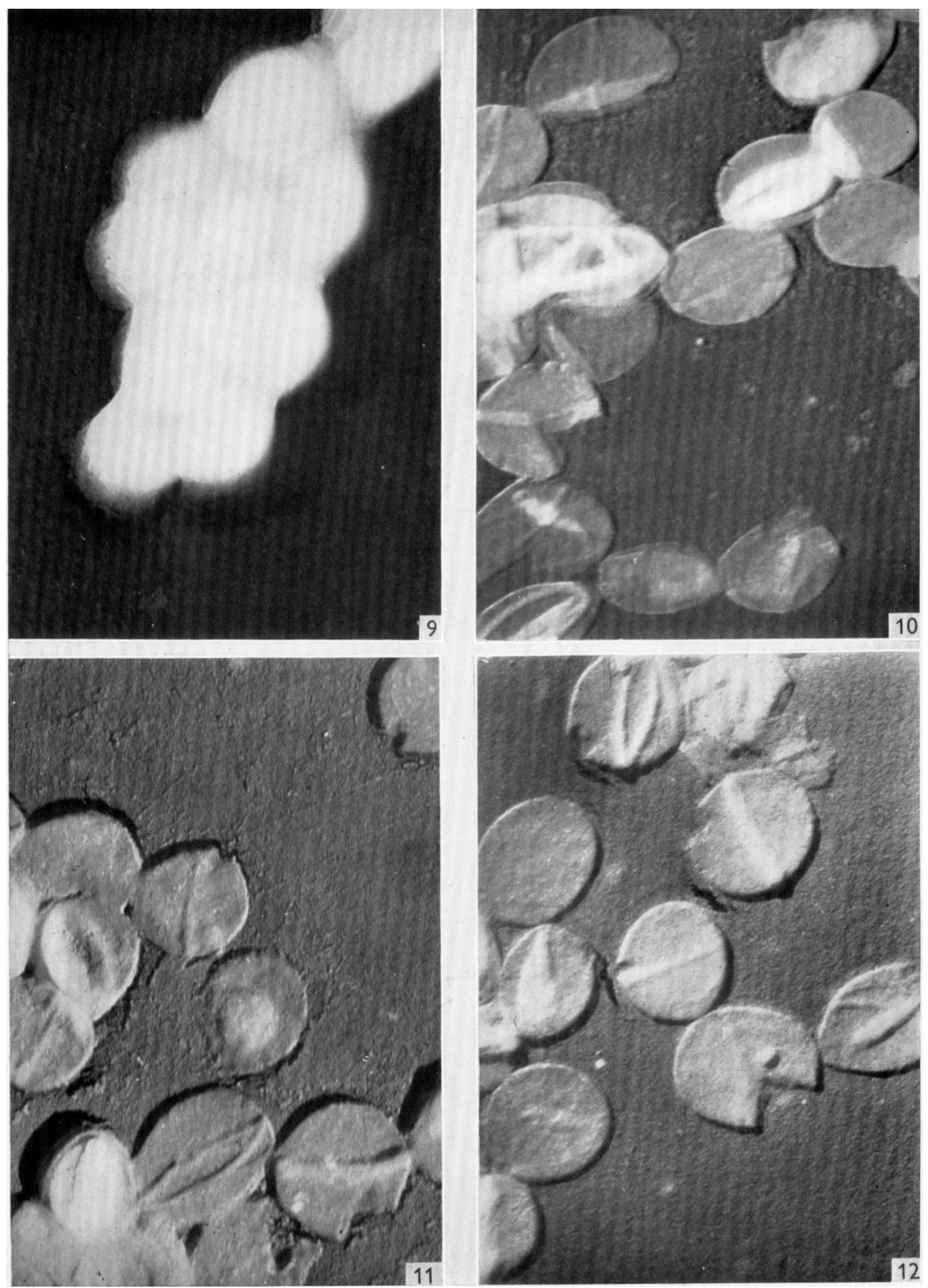

A. V. Few-Polymyxin-treated disrupted bacteria. Plate 3 